DOI: $10.31866 / 2410-1915.20 .2019 .172418$

УДК 122/129

\title{
АБСОЛЮТ, ІДЕЯ, ІДЕАЛ У ФІЛОСОФСЬКІЙ ТРАДИЦІї
}

\section{Легенький Ілларіон Юрійович}

Кандидат філософських наук, ORCID:0000-0003-4619-9281, illarion.leg@gmail.com, Національний педагогічний університет імені М. П. Драгоманова, вул. Пирогова, 9, Київ, Україна, 02000

Мета дослідження - експлікувати категорію «абсолют» у філософській рефлексії як граничну настанову культуротворчості, мистецтва. Об’єктом наукового дослідження $є$ єдність філософської та культурологічної рефлексії, предметом наукового дослідження $є$ категорія «абсолют» у філософській рефлексії. Методологія дослідження базується на культурно-історичній реконструкції абсолюту як безумовного, необмеженого принципу, як філософської категорії, яка визначає основу світобудови, повноту буття і досконалість світу. Для цього були використані методи аналізу та синтезу, структурний метод, системний та компаративний підходи. Наукова новизна полягає у тому, що визначені онтологічні означувані абсолюту: основа, повнота як певна ціннісна метрика (інтенсивної та екстенсивної) вдосконалення світу людини, прагнення досягти найвищого ступеня гармонії, яка рефлектується в єдності людини і світу. Висновки. Отже, можемо стверджувати, що після Другої світової війни філософи відкрили світ екзистенційної нескінченності буття, коли К. Яперс починає говорити про метафізичну провину, а ще більш відверто це засвідчив М. Бубер, який стверджує, що прадистанціювання як ставлення людини до Бога є основою ставлення людини до людини. Ці філософи породжують такі ходи думки в філософії, які, безумовно, стосуються Абсолюту як ідеалу. Зауважимо, що питання про Абсолют $€$ нескінченним, як і питання про сутність філософії в її традиції, але воно має своє ядро, яке корениться в тому, що телеологія як цілепокладання у людському бутті знаходить свою завершеність у теоцентризмі, діалозі або полілозі з Абсолютом, зустрічі з великим Іншим. Думка-зустріч феноменологічно чітко структурована як конституювання «Я» і світу одночасно, як конституювання Абсолюту. Це дає надію і бентежить одночасно, допомагає зрозуміти, що існування «Я» в іншому, інобуття це певна відчуженість як інобуття «Я» музиканта, виконавця, композитора, філософа.

Ключові слова: світ; людина; абсолют; рефлексія; філософія; культура; всеєдність.

\section{Вступ}

Абсолют постулюється як надмірна істота поза людським світом або, навпаки, існує «тут» і «там». Це принцип панєнтеїзму, який виник в Індії, в неоплатонізмі. Всі імплікації Абсолюту як досконалості, абсолютної істини, абсолютного початку вимагають його генеалогічної ідентифікації в історії філософії. Категорія «абсолют» була визначена в філософії

() Легенький І. Ю., 2019 
Стародавнього Сходу, Платона, Аристотеля, Плотіна, Августина, Діонісія Ареапагіта, Лейбнітца, Канта, Гегеля, російської філософії Срібного століття, яка зафіксувала тотожність людини і світу в таких категоріях як «всеєдність» у Вл. Соловйова, «софійність» у П. Флоренського та ін. Абсолют ототожнюється з божественним початком або навіть 3 самим Богом.

Актуальність наукової розвідки полягає у тому, категорія «абсолют» досліджується як метахудожні філософська універсалія у контексті культуротворчості вперше. Естетичні виміри абсолюту визначаються як культуротворчи настанови - епістема, технема, софія.

Питанням абсолюту, ідеї та ідеалу присвячена значна кількість наукових досліджень. Зокрема, Г. Майоров у книзі «Філософія як шукання абсолюту» присвятив багато сторінок експлікації філософського бачення цієї категорії. Важко навіть сказати, як можна укласти те, що ми розуміємо під словом абсолют в категоріальний ряд всіх інших філософських дефініцій. Якщо цю категорію розуміти як певне узагальнення і диференціацію реальності, на відміну від поняття, яке вже є звужена категорія, то, безумовно, абсолют завжди знаходиться на межі виходу за всілякі категоріальні рамки. Можна говорити, що еквівалентом абсолюту $є$ абсолютна істина як неприховане, за М. Гайдеггером. Завжди існує те, що належить більш далекій, глибшій основі. Вся платонівська філософія, просвящений неоплатонізм, який виникає в різні часи, за О.Лосєвим, містить еквівалент прихованого і неприхованого, визначає якусь містеріальну грань якоїсь потойбічної любові, яка рефлектує в акті наукового самозаперечення, всього того, що Лосєв називав відчуженістю, опановує і не опановує предмет своєї любові і мудрості.

Філософ виходить 3 попередніх світів, концептів, знань про світ і завжди на межі прийти в якийсь інший світ, який непідвладний філософії. У цьому суть філософії. Якби філософи відкривала світи, як якісь сходинки, за якими людина крокує в верх сходами Якова, і врешті-решт добирається до певної невідомої вежі, де перебуває Абсолют, то це була б не філософія. Любов була б не потрібна, а мудрість тим більше. Мудрість - це завжди розчарування, якесь осмислення вдачі, невдачі і всього того, що філософія здійснювала в своїх дослідженнях. Ідеалізм Платона виник і досяг своєї досконалості після того, як філософ був проданий в рабство. Він зрозумів низ, падіння людини в рабському стані, захотів відірвати людини від рабства, з яким ототожнював перебування людини на землі. Платон універсуалізіровал рабський стан людини, представив світ як печеру, населену тіннями абсолюту.

Цей універсалізм по суті вже є християнське поняття, яке виникло на останній драбинці буття «тут», перед смертю світу, перед очікуванням цієї смерті. Екзистенційна філософська іпостась мудрості, безумовно, говорить про те, що філософська рефлексія завжди $є$ індивідуальною, завжди $\epsilon$ відкритістою в інше, $\epsilon$ алетея, істина або напівзачине апофатичне визначення, і в той же час філософія завжди залишає можливість перспективи. Якби цього не було, вона не бьла б мудрістю. Перспективи життя після смерті, перспективи метемпсихозу, переселення 
душ, перспективи зустрічі з іншими світами, і врешті-решт - зустріч 3 Абсолютом, що переживається містеріально, літургійно, визначається як обмін натурами, як синергія, енергетичний колапс, осяяння, катарсис. I разом 3 тим, ця зустріч експліціруется як епістема, інтерпретується, осмислюєтюся як категорія «світ».

Абсолют як філософська категорія реконструюється в контексті етикоестетичних проблем, в екзистенційному просторі міфопоетикі буття О. Лосєвим， В. Бичковим，Я. Голосовкером，С. Кримським， Г. Майоровим та ін. (Лосєв, 1994; Бычков, 2012; Голосовкер, 2010; Крымский, 2008; Майоров, 2017). Однак недослідженою залишається категорія «абсолют» в їі співвіднесені з інтенсивними та екстенсивними процесами культуро творчості, які дають характеристику художнього простору.

\section{Мета статті}

Експлікувати категорію «абсолют» у філософській рефлексії як граничну настанову культуротворчості, мистецтва. Об’єктом наукового дослідження $\epsilon$ єдність філософської та культурологічної рефлексії, предметом наукового дослідження є категорія «абсолют» у філософській рефлексії.

Методологія дослідження полягає у культурно-історичній реконструкції абсолюту як безумовного, необмеженого принципу, як філософської категорії, яка визначає основу світобудови, повноту буття і досконалість світу. Дя цього були використані методи аналізу та синтезу, структурний метод, системний та компаративний підходи.

\section{Виклад матеріалу дослідження}

Піфагор традиційно вважається першим, хто говорив про провидіння, був близький до східної філософії, ведичної традиції. Піфагор був і великим містиком, пов'язаним з орфічними містеріями. Саме тут метемпсихоз став межею філософствування, таємниця метемпсихозу опановує певний музичний космос, де відтворюється гармонія космологічного, музичного зразка. Усе це дає цікаві посилання, які так чи інакше можна знайти в індійських Ведах, в іранській Авесті. Можна говорити про те, що все, що у гностиків визначалося як світове яйце, Софія, яка ще не стала християнською, а була лише певним чином космологічної мудрості, у Піфагора зазвучала як мудрість, яка так би і не стала б філософською, якщо б не орфізм і аполлонічний культ, який ототожнював Аполлона з Сонцем. Піфагор шанувався як Аполлон Гіперборейський. Орфізм у Піфагора «математизується», в основу космології було покладено число (Жмудь, 1994). Число обожнювалося. Усе це потім було блискуче доведено до певної системи в неоплатонізмі, де числа еманують з єдиного, а 3 цих чисел (богів) еманірують світовий розум, світова душа, космос і людина.

Ця деградаційна стратегія належала всім древнім культурам, однак вона змінюється в християнстві, де людина стає верхівкою всього сутнього на землі. Але, щоб цей переворот або поворот відбувся, потрібно було 
дуже багато пережити, філософія, особливо неоплатонізм, що виник після двох століть християнства утворив цю модель (по суті платонівську), що зберігала світ ідей, який був імперсональним, космологічним, спирався на пифагорейскі числа, пізніше Платонова тіла (куля, куб, піраміда та ін.), що по суті були першоосновою світобудування, адже так чи інакше маркували абсолютний вимір світу.

Згідно Проклу, який інтерпретував Піфагора, його манера філософствування була своєрідним таїнознавством, тяжіла до оккультного відтворення вчення, а школа - орфічна і математична, передгностична тяжіла до того, щоб бути більш загальним цілим, ніж філософія. Це була філософська містерія, літургія єдності людини і світу. Усе це зараз набуває актуального значення, коли людина диференційована, людина самотня, людина розбита на функції, специфікована шукає якісь аналоги гармонії і цілісності і, безумовно, не завжди знаходить.

Усі наступні трансформації Абсолюту, за Г. Майоровим, мали присмак еклектики, до речі, вже Піфагор об’єднував рефлектовані східні інтенції та еллінські інтуїції. Коли Лосєв каже, що Канта називають еклектиком, то 3 тією же підставою можна вважати, що вже і Платон був еклектиком. Платон узагальнив досвід філософствовання минувшини, це узагальнення мало настанови мімезису, міметичного збирання ейдосів. Мімезис в філософії є більш фундаментальним, ніж катарсис. Але рушійною силою любові до мудрості є все ж таки катарсис - очищення почуттів як ерос, динаміка прориву в інобуття, яка дається філософу зовсім не легко. Будьякий великий філософ - не тільки мудрець, не тільки любомудр, не тільки той, хто конструює світи і світобудови, рухає ними, знаходить імена цим системам, створює, зрештою, свою систему, - це, насамперед, людина, яка знаходиться між світами. Філософ відкриває той світ, який прихований, $\epsilon$ початком істини, який можна визначити або апофатично, як це робив Діонісій Ареопагіт, або, навпаки, катафатично, з тієї рішучістю, як це робив Арістотель.

Любов до мудрості завжди пов’язана з певним етосом. Етос, за Гераклітом, - це місце, де можливо божество. На гераклітовому визначенні етичного витоку наполягав М. Хайдеггер в роботі, присвяченій аналізу європейского нігілізму. Гайдеггер пише, що онтологічне розуміння етики, ейдосу тяжіє до абсолюту. Бог, Абсолют стають горизонтом істини, яка і прихована, і відкрита одночасно (Хайдеггер, 1993). Етос - вище благо, це добро, яке так чи інакше діє, існує у відкритому просторі, його можна інтерпретувати по-різному. Як світло, що засліплює, наприклад, - про це пишуть Платон, Плотін та ін. Найяскравіше світло дорівнює темряві людина сліпне. Середньовічний принцип люмінізму свідчить, що світло $\epsilon$ континуальним і дискретним в один і той же час. Світло $є$ дискретним тому, що доходить до людини у вигляді точок-зірок на небі. Небо - це «сито», в якому ці зірки-точки є лише блідим відбитком недоступного далекого світла.

Європейський люмінізм вказує на те, що світло є принципом блага або субститутом Бога, люмінізм як світло-розум дійшов до нас у відображенні 
середньовічного, еллінського - більш раннього світогляду. Абсолют з самого початку філософії свідчив про єдність істини і добра, але, безумовно, ерос як породження в красі домінує в філософії Платона, який після зустрічі з Сократом змінив свій тип філософствування, а після того, як його викупили 3 рабства, рефлексія Платона стає ще більше категоричною, естетичною. Охоплена любов’ю Еросу і охоплена загальною ідеєю блага, людина породжує в красі той світ, де почуття, розум, інтуїція і досвід переживання світу становить певну цілісність, яку можна визначити як витвір мистецтва, релігійну цілісність, religare - зв’язування всього сутнього.

Філософську світобудову можна визначити як епістеміологічну, як епістему, рефлективну категорію наукового типу. Але за цим ховається все ж таки щось незрозуміле, що музика і мистецтво взагалі, філософія та релігія специфікують, ідентифікують, інтенсифікують. Кожна практика культури рефлектує і відображує приховане і неприховане, має в середовищі свого самовираження і самоздійснення ту ступінь відчуженості (абстрактності або екзистенційної іншості), про яку говорив Лосєв. Не можна сказати, де вона $є$ більшою, а де меншою. Чи в релігії як екстазі, відчаї, одкровенні, чи в філософії, де відчуженість досягає останнього шляху як абстрагування або гипостазирования абстракцій, або в мистецтві, де естетичний суб'єкт, як О. Скрябін, наприклад, ототожнює себе з Богом, ніщо, початком і кінцем світу. Усе це, так чи інакше, передбачає, що всеєдність про яку мріяв В. Соловйов, завжди мислиться як недосяжний, далекий образ. Але цей образ цікавий, він вражає.

Усі відносини людини і Абсолюту починаються з того, що людина ïх опосередковує. Опосередковує ставленням до природи, культури, до іншої людини. Найдраматичне опосередкування, як вже показало третє тисячоліття, - це ставлення людини до природи, що перетворилося в якусь тотальну конфліктологію, якщо не війну. Г. Майоров пише: «Як би не підносилася людина, як не куражилася, вона завжди залишається сином (блудним) природи, прахом земним, наділеним від Бога свідомістю. Ніяка наука не здатна змінити людське походження і не може відірвати людину від її природних коренів, не погубивши її при цьому. I поки коріння ціле, рухаються по ним соки Матері-Землі, що живлять ї̈ тіло і душу, мають у собі енергію життя, фортеця пам'яті - пам'ятати про щіру і теплу утробу природи, в якій була зачата людина. Як це сталося, ми благочестиво промовчимо» (Майоров, 2017, с. 29). Коли все перекладається на мову зачаття, креації, породження, а потім вже діяльності, практики, всіх інших супутніх реалій (культивації природи, культурних практик, їх диференціації), то тут же в цьому нескінченному опосередкуванні втрачається те, що ми називаємо глибинний зв'язок людини і світу, що починається з міфу, який ніколи не покидав культуру. Але чомусь міфопоетичні витоки культуротворчості редукуються.

Греки не відкрили філософію, але надали їй інше дихання, висловили те основне, що мудрість, софійний аспект орієнтовані на щось більше, ніж однозначне ставлення до природи, світу, все те, що ми пов'язуємо з науковим вивченням реальності. Г. Майоров дає три визначення філософської 
рефлексії, які, на наш погляд, допоможуть осмислити реальність відношення до Абсолюту в мистецтві, особливо в музиці. «Отже, ми стверджуємо, що греки не тільки відкрили для нас філософію, а й вичерпали всі основні способи її розуміння, - пише Г. Майоров. - Тепер наше завдання довести це. Насамперед, дамо цим способам (типам) розуміння відповідні їх сутності назви. Перший, оскільки він орієнтований на мудрість, назвемо «софійним» (від грец. sopia - мудрість); другий, орієнтований на науку, назвемо «епістемічним» (від грец. еріsteme - «точно встановлене знання», «наука»); третій, орієнтований на майстерність, винахідливість і сприйнятність мислення, одним словом - на техніку, назвемо «технематічним» (від грец. technema - «майстерний твір», «вигадка», «інтрига», «сприйнятний трюк» та ін.» (Майоров, 2017, с. 36).

Можна сказати, що в музиці - предметі нашого наукового дослідження $\epsilon$ наявними ці три компонента. Останній - це виконавський аспект, що $€$ найближчим до онтології музики, бо вона живе тільки інтерпретацією, виконанням. Другий пов’язаний з рефлексією і взагалі з усією системою нотацій, переданням інформації, комунікацією в музичному світі. I перший, власне софійний, пов'язаний з творчим витоком музичного космологізму, який ніколи не залишав музику і навряд чи почався з Піфагора, бо існував завжди. Отже, софійний, епістемний і технематичний аспекти складають епіцентр музичного мистецтва як такого, є носіями пророчого дару, істини, комунікативної, рефлективної свідомості.

Технематичний, техногенний характер музики привносить нові технології, зокрема і візуальні, комп’ютерні, кібернетичні в світ тієї онтологічної сутності звучання, яка стає або електронно-детермінованою або залежить від тих копій, відбитків, які залишаються після звучання музики. Можна сказати, що екзистенційне випробування філософії - це пострефлексія над цикутою Сократа, рабством Платона, стратою Боеція. Можна продовжувати перерахування великих і малих катастроф філософів, що може наблизити до Томаззо Кампанелла і до інших філософів, поетів, художників, композиторів. Езистенційне випробування свідчить про те, що людина в її абсолютних інтенціях, у пориві до безмежного не може бути самотньою, завжди спирається на ближнього, шукає відзвуки своїх передбачень в тому, що не приховано, існує поруч з нею. Шукає в тому, що С. Рубінштейн назвав «республікою суб’єктів» в одному суб’єкті етики, в одному продуценті ціннісних засад буття.

Вже Платон, спираючись на сократовское розуміння Абсолюту як абсолютного добра, блага, абсолютної істини, підійшов до ідеї породження в красі або породження красою, підійшов до того, що феномен естетичного став епіцентром його філософствування. Лосєв визначив Ерос в статті «Ерос у Платона» як зв'язок з небесною батьківщиною. «Як і будь-яке мистецтво, - пише Г. Майоров, - філософія рухає красою, трансцедентною і в той же час трансцедентальною Красою Абсолюта, що надає душі філософа натхнення, а оскільки натхнення від краси $є$ любов, ерос, то філософ є ніщо інший, як тип закоханого, з усіма властивостями закоханої душі, серед яких найхарактерніше - несамовитість, вихід з буденності, вихід за межі звичної раціональності, що приймається іншими людьми за чудакуватість 
(згадаємо платонівського Сократа в «Бенкеті» i «Теететі»). Виходячи з цього, Платон оголошує Богом-покровителем філософії Ерота і вносить тим самим в розуміння її новий екстатичний елемент: пифагорейськую та сократівський «філію», спокійну і врівноважену любов-дружбу чи любовприхильність, він перетворює в любов-ерос, тобто любов-екзальтацію, любов-порив, що одвічно тягне філософа з області, що минає, недосконалого світу в область вічного і досконалого, а тому у всіх сенсах ідеального. Туга за ідеальним як раз і складає головну відміну ознаки філософії у вченні Платона. Ось чому в центрі його уваги знаходиться теорія ідей, ця теорія покликана довести, що філософський ерос і прагнення людини до повноти буття, тобто до безсмертя і досконалості не безпідставні і що досконале, і повне передує недосконалому, і неповному як логічно, так і онтологічно» (Майоров, 2017, с. 41).

Туга, екстаз, порив, амнезис, ерос, який прокидається щоранку на порозі невідомого будинку - всі категорії нагадують якийсь невгамовний персонаж сократичного типу. Усе це стало можливим після смерті Сократа і після перебування в рабстві Платона. Переступивши через смерть і через рабську іпостась свого «Я» Платон облаштував небесну батьківщину і спробував втікти в інший світ, що йому вдалося, і не вдалося. Можна сказати, що софія, епістема і технема цієї втечі виявилися по-різному. Так, завжди буде радіти технема як якийсь дивовижний дискурс, техніка витонченого діалогу. Епістема страждає від темряви, провалин, а софія весь час спустошує думку і живе передчуттями всього того, що потім виникло в християнстві. Про це добре писав Лосєв, коли говорив про самотність творчості, про досвід перебування в стані відчуженості.

Таким чином, абсолют, обтяжений нескінченністю, а світ речей, світ творів позбавлений iї, і завдяки цьому він $є$ особливо близький людині. Людина має відношення до нескінченності, Абсолюту, але це відношення опосередковане, через світ близьких речей і творів. Ця ідея проходить через всю філософію в різних іпостасях, різних варіантах, то загострюється, згасає, адже не зникає з горизонту. Варто зазначити, що проблема абсолюту в філософії актуалізує проблему людини. Усім відомо, що найбільшим поборником філософської антропології був Кант. Його відомі питання: що я можу знати, що мені належить робити, на що можу сподіватися узагальнюються в одному питанні: що є людина? У всякому разі, всі питання в такій же мірі адресовані Абсолюту. Усі кантівськи критики в більшій мірі це філософсько-антропологічні реалії ставлення до Абсолюту. Особливо це гостро виражається в кантівській етиці, тотожній, за великим рахунком, 3 біблійної мудрістю і біблійної етикою, в естетиці, яка має проект гуссерлівскої феноменології. Гуссерль редукував феноменологію Канта, бо його феноменологія пішла від кантівського імперативу явленносіті речі, замінила його необов’язковістю ставлення до світу - конституюванням.

\section{Висновки}

Отже, можемо стверджувати, що після Другої світової війни філософи відкрили світ екзистенційної нескінченності буття, коли К. Яперс починає 
говорити про метафізичну провину, а ще більш відверто це засвідчив М. Бубер, який стверджує, що прадистанціювання як ставлення людини до Бога $є$ основою ставлення людини до людини. Ці філософи породжують такі ходи думки в філософії, які, безумовно, стосуються Абсолюту як ідеалу. Можемо зауважити, що питання про Абсолют є нескінченним, як і питання про сутність філософії в її традиції, але воно має своє ядро, яке корениться в тому, що телеологія як цілепокладання у людському бутті знаходить свою завершеність у теоцентризмі, діалозі або полілозі з Абсолютом, зустрічі 3 великим Іншим. Думка-зустріч феноменологічно чітко структурована як конституювання «Я» і світу одночасно, як конституювання Абсолюту. Це дає надію і бентежить одночасно, допомагає зрозуміти, що існування «Я» в іншому, інобуття - це певна відчуженість як інобуття «Я» музиканта, виконавця, композитора, філософа.

\section{Список використаних джерел}

1. Барт Р. Избраннные работы: Семиотика. Поэтика. Москва : Прогресс, 1994. $616 \mathrm{c}$.

2. Бычков В. В., Маньковская Н. Б., Иванов В. В. Триалог. Москва : ПрогрессТрадиция, 2012. 840 с.

3. Бубер М. Два образа веры. Москва : Республика, 1995. 464 с.

4. Голосовкер Я. Избранное: логика мифа. Москва : Центр гуманитарных инициатив ; Санкт-Петербург : Университетская книга, 2010. 496 с.

5. Жмудь Л. Я. Наука, философия и религия в раннем пифагореизме. Санкт Петербург : Алетея, 1994. 376 с.

6. Крымский С. Б. Философия как путь человечности и надежды. Киев : Курс, 2000. 308 c.

7. Лосев А. Ф. Мир. Число. Сущность. Москва : Мысль, 1994. 919 с.

8. Майоров Г. Г. Философия как искание абсолюта: опыты теоретические и исторические. Москва: ЛИБРОКОМ, 2017. 416 с.

9. Хайдеггер М. Время и бытие. Москва : Республика, 1993. 448 с.

\section{References}

Bart, R. (1994). Izbrannnye raboty: Semiotika. Poetika [Selected Works: Semiotics. Poetics]. Moscow: Progress.

Buber, M. (1995). Dva obraza very [Two images of faith]. Moscow: Respublika.

Bychkov, V.V., Mankovskaya, N.B. and Ivanov, V.V. (2012). Trialog [Trialogue]. Moscow: Progress-Traditsiya.

Golosovker, Ya. (2010). Izbrannoe: logika mifa [Favourites: myth logic]. Moscow: Tsentr gumanitarnykh initsiativ; St. Petersburg: Universitetskaya kniga.

Khaidegger, M. (1993). Vremya i bytie [Time and being]. Moscow: Respublika.

Krymskii, S.B. (2000). Filosofiya kak put chelovechnosti i nadezhdy [Philosophy as a way of humanity and hope]. Kyiv: Kurs.

Losev, A.F. (1994). Mir. Chislo. Sushchnost [World. Number. Essence]. Moscow: Mysl. 
Maiorov, G.G. (2017). Filosofiya kak iskanie absolyuta: opyty teoreticheskie i istoricheskie [Philosophy as the research for the absolute: theoretical and historical experiences]. Moscow: LIBROKOM.

Zhmud', L.Ya. (1994). Nauka, filosofiya i religiya $v$ rannem pifagoreizme [Science, philosophy and religion in early Pythagoreanism]. St. Petersburg: Aleteya.

Стаття надійшла до редакції: 27.03.2019

\title{
ABSOLUTE, IDEA, IDEAL IN A PHILOSOPHICAL TRADITION
}

\author{
Illarion Lehenkyi
}

PhD in Philosophy, ORCID: 0000-0003-4619-9281, illarion.leg@gmail.com, National Pedagogical Dragomanov University, Kyiv, Ukraine

The aim of the research is to explain the category of the «absolute» in philosophical reflection as an ultimate goal of culture work and art. The object of the scientific research is the unity of philosophical and cultural reflection; the subject of the scientific research is the category of the "absolute" in philosophical reflection. The methodology of the research is based on the cultural-historical reconstruction of the absolute as an unconditional, unrestricted principle, as a philosophical category, which determines the basis of the universe, the fullness of being and the perfection of the world. For this purpose, methods of analysis and synthesis, structural method, systemic and comparative approaches were used. The scientific novelty of the research is about defining the certain ontological concepts of the absolute as follows: the basis, completeness as a certain value metric (intensive and extensive) of perfection of the human world; the desire to achieve the highest degree of harmony that is reflected in the unity of Man and the World. Conclusions. Consequently, we can say that after World War II the philosophers discovered the world of existential infinity of being, when K. Yapers started to talk about metaphysical guilt, and M. Buber was more direct, when said that the pre-distancing of man attitude to God is the basis of attitude man to man. These philosophers generate such moves of thought in philosophy, which, of course, relate to the Absolute as the Ideal. It is worth mentioning that the question of the Absolute is infinite, as well as the question of the essence of philosophy in its tradition, but it has its core, which is rooted in the fact that teleology as a goal-setting in human existence finds its completeness in the Theocentrism, in a dialogue or polylogue with the Absolute, meeting with a great Another. The thought-meeting is phenomenologically clearly structured as the constitution of "the I" and the world at the same time as the constitution of the Absolute. It gives hope and confusion at the same time; it helps to understand that the existence of "the I" in another, anderssein is a certain strangeness as another "the I" of a musician, performer, composer, and philosopher.

Keywords: peace; man; absolute; reflection; philosophy; culture, unity. 


\section{АБСОЛЮТ, ИДЕЯ, ИДЕАЛ В ФИЛОСОФСКОЙ ТРАДИЦИИ}

\section{Легенький Илларион Юрьевич}

Кандидат философских наук, ORCID: 0000-0003-4619-9281, illarion.leg@gmail.com, Национальный педагогический университет им. М. П. Драгоманова, Киев, Украина

Эксплицировать категорию «абсолют» в философской рефлексии как предельную установку культуротворчества, искусства. Объектом научного исследования является единство философской и культурологической рефлексии, предметом научного исследования является категория «абсолют» в философской рефлексии. Методология исследования заключается в культурно-исторической реконструкции абсолюта как безусловного, неограниченного принципа, как философской категории, которая определяет основу мироздания, полноту бытия и совершенство мира. Для этого были использованы методы анализа и синтеза, структурный метод, системный и компаративный подходы. Научная новизна заключается в том, что определены онтологические обозначенные абсолюта: основа, полнота как определенная ценностная метрика (интенсивной и экстенсивной) совершенствование мира человека, стремление достичь высокой степени гармонии, которая рефлектируется в единстве человека и мира. Выводы. Итак, можно утверждать, что после Второй мировой войны философы открыли мир экзистенциальной бесконечности бытия, когда К. Яперс начинает говорить о метафизической вине, а еще более откровенно это показал М. Бубер, который утверждает, что прадистанциирование как отношение человека к Богу является основой отношения человека к человеку. Эти философы порождают такие ходы мысли в философии, которые, безусловно, касаются Абсолюта как идеала. Заметим, что вопрос о Абсолюте является бесконечным, как и вопрос о сущности философии в ее традиции, но оно имеет свое ядро, которое коренится в том, что телеология как целеполагание в человеческом бытии находит свою завершенность в Теоцентризм, диалоге или полилоге с Абсолютом, встречи с большим Другим. Мысль-встреча феноменологически четко структурирована как конституирования «Я» и мира одновременно, как конституирования Абсолюта. Это дает надежду и смущает одновременно, помогает понять, что существование «Я» в другом, инобытие - это определенная отчужденность как инобытие «Я» музыканта, исполнителя, композитора, философа.

Ключевые слова: мир; человек; абсолют; рефлексия; философия; культура; всеединство. 